Oliwier MENDALA ${ }^{1}$, Katarzyna TOKARSKA ${ }^{2}$

${ }^{1}$ University of Economics in Katowice (Uniwersytet Ekonomiczny w Katowicach)

${ }^{2}$ PwC Service Delivery Center, PwC Polska

\title{
AVIATION CRIMINAL LAW REGULATIONS OF THE TOKYO CONVENTION AND THE PENAL CODE TO COUNTERACT TERRORIST ACTS
}

\section{Lotnicze prawo karne. Regulacje Konwencji tokijskiej oraz Kodeksu karnego w celu przeciwdzialania aktom terroru}

\begin{abstract}
The aim of the study is to present issues related to acts of terror and attempts to counteract them, whose subject matter of which is governed by a number of legal acts of various territorial scope, primarily by regulations contained in the Tokyo Convention, which is a source of public international law, and Polish normative acts, such as the Aviation Law together with legal and penal regulations. The paper presents considerations aimed at indicating the proper interpretation of the provisions regulating the obligation to undertake investigative and explanatory actions as part of pre-trial proceedings conducted by the prosecutor, the issues of jurisdiction and competence of the courts adjudicating in criminal cases, and the issues concerning the institution of extradition and its legal basis.
\end{abstract}

Keywords: act of terrorism, institution of extradition, international and territorial legal acts related to terrorism, jurisdiction of adjudicating courts of law

Streszczenie: Celem opracowania jest przedstawienie zagadnień zwiąanych z aktami terroru oraz próbami przeciwdziałania im, których materia uregulowana jest przez szereg aktów prawnych o różnym zasięgu terytorialnym, przede wszystkim poprzez regulacje zawarte w Konwencji tokijskiej, będacej źródtem prawa międzynarodowego publicznego, akty normatywne polskie, takie jak ustawa Prawo lotnicze wraz z regulacjami prawno-karnymi. W artykule przedstawiono rozważania majace na celu wskazanie właściwej wykładni przepisów regulujących obowiązek podjęcia czynności śledczych i wyjaśniajacych postepowania przygotowawczego prowadzonego przez prokuratora, kwestie jurysdykcji $i$ właściwości sądów orzekających $w$ sprawach karnych oraz kwestie dotyczace instytucji ekstradycji oraz jej podstaw prawnych.

Słowa kluczowe: akt terroru, międzynarodowe i terytorialne akty prawne związane z terroryzmem, jurysdykcja sądów orzekających, instytucja ekstradycji 


\section{Introduction}

In doctrine, the concept of aviation criminal law has developed as all legal norms regulating the process of prosecution and imposition of punishment for crimes and offences committed against the good, such as the air navigation system. Such criminal acts may also involve concern for human health and life as well as for property [32]. The regulations underpinning the aviation criminal law are mainly governed by the so-called Tokyo-HagueMontreal system, comprising three international conventions agreed under the auspices of the ICAO (International Civil Aviation Organization) which are binding on all State parties [15]. The Convention on Offences and Certain Acts Committed on Board Aircraft [10], drawn up in Tokyo on 14 September 1963, obliges the signatory states to exercise jurisdiction over offences committed on board an aircraft of the state of its registration. Every possible measure should be taken for the state of registration of the aircraft to designate its own jurisdiction in the event of an offence being committed on board such an aircraft. Following the designation of jurisdiction, when undertaking investigations it is necessary to take into account the safety and interests of air navigation, and not to cause undue disruption to the aircraft. A state which is not the state of registration is not entitled to paralyse an aircraft flight for the exercise of its jurisdiction, except as provided by the Convention. The exceptional cases referred to in Article 4 refer mainly to protection of safety of the state concerned.

\section{Aviation criminal law - international and state regulations on the prosecution of crimes and offences in aviation}

The making use of Polish criminal legislation takes place when a prohibited act has been committed on the territory of the Republic of Poland, as well as on board a Polish vessel or aircraft, unless an international agreement to which the Republic of Poland is a party provides otherwise. The Penal Code [24] has not formulated the concept of "the territory of the Republic of Poland", however, the Act of 12 October 1990 on the Protection of the State Border [23] provides a definition of this area. The Polish territory is understood as the area contained within the state borders, separating the territory of the Republic of Poland from the territories of other states and the open sea, and the internal waters and the maritime belt of territorial waters, as well as the airspace above this area and the interior of the land beneath it. The airspace above the territory of the Republic of Poland is delimited by the space border, which has its origin in the place where the lowest orbits of artificial satellites of the Earth pass, which is about 90 kilometers [31]. The application of the Polish Penal Code is extended to Polish, i.e. registered in Polish, aircraft and watercraft which do not, however, form part of the territory of the Republic of Poland [12]. According to Article 31 of the Code of Penal Proceedings [25], the court with jurisdiction to hear the case is the 
court in whose district the offence was committed. It is the duty of the court to hear the case, because of the location of the incident, where the offender acted or failed to act. In the case when an offence is committed on a Polish ship or aircraft, the competent court is the court of the ship's home port due to the ship staying outside the borders of the Republic of Poland, unless it is possible to apply the previously indicated rule [4].

M. Żylicz points out that at the level of the aviation criminal law we should distinguish international offences, whose prosecution is obligatory for the states which are parties to relevant international conventions, which after proper implementation become an element of the national law system, as well as offences typified by national legislations and those penalised by internal law systems [32]. Beginning with a discussion of the first of these categories of offences and their catalogue, it is worth giving a general overview of the institution of delicta iuris gentium, translated in many ways, i.e. offences under international law, convention offences or offences under the law of nations. The offences provided for in international agreements enable, and at the same time oblige, all signatories to the agreement to prosecute them and punish for them. The catalogue of acts is not enumerative, and examples include aviation terrorism, taking the crew of an aircraft hostage, and maritime piracy [2]. The pacification of these unlawful acts is not the responsibility of one state alone, but is the duty of the entire international community due to the threat to all humanity [18].

The principle of universal repression has been incorporated by the legislator in the Polish Penal Code, which in Article 113 provides that, regardless of the provisions in force in the place where the offence is committed, the Polish Criminal Law shall be applied to a Polish citizen and to a foreigner who has not been ordered to be extradited, if they commit abroad an offence which the Republic of Poland is obliged to prosecute under an international agreement, or an offence defined in the Rome Statute of the International Criminal Court (ICC) drawn up in Rome on 17 July 1998 (J/L of 2003, item 708). The nationality of the perpetrator is irrelevant, and so is the place where the offence was committed, since the principle of universal repression allows prosecution which is not restricted by the territoriality principle. The Republic of Poland, by signing international treaties, is obliged, in accordance with its own criminal legislation, to bring the perpetrator before a Polish court in a situation where it has not decided to surrender such a person to a foreign state, nor has any state submitted a request for such surrender [6]. The acts penalised by the ICC Statute complete the catalogue of offences defined by international treaties, which do not need to be introduced into domestic criminal law systems. Such a procedure is intended to protect Polish citizens who have committed a criminal act outside the territory of the Republic of Poland and in the case of whom the requirement of double punishability has not been realised, and Poland has not been obliged to prosecute them [2]. Persons suspected of committing offences included in the ICC Statute are primarily subject to the national jurisdiction, as the ICC's jurisdiction is of a complementary nature to domestic legal systems. These acts are classified as the most serious international crimes, which include genocide, aggression, war crimes and crimes against humanity, and have no statute of limitations [6]. 
At this point, selected international offences contained in the Chicago [7] and Montreal [9] Conventions should be presented, some of which have been faithfully reproduced by the Polish legal system, while some of them have been adopted fragmentarily only or deviate from the convention definitions. Article 3 bis of the Chicago Convention addresses the issue of interference with a state's sovereignty over its sky territory. As a consequence of recognising that each party to the Convention is obliged to refrain from taking action with weapons in relation to a foreign aircraft, it cannot be considered required to refrain from any action in the event of overflight of an aircraft without the required authorisation or used for a purpose contrary to the arrangements of states. In the absence of authorisation, such a state may intervene by requiring landing in a particular airport or by issuing other instructions to restrain the unlawful conduct, which are commensurate with the accepted principles of the international community, and any aircraft involved is obliged to comply with such directives of the state. The signatory states are required to regulate this issue in such a way that the penalty imposed must be restrictive and commensurate with the offence committed, and the analysis of each offence should be made known to the competent authorities. An elaboration of the obligations of aircraft in the airspace of a foreign state is Article 12, which requires respecting the rules and legislation concerning flights and operation of an aircraft applicable in a particular territory. These provisions should be reflected in national law systems in a very precise, reliable and multifaceted way. The Polish legislator decided, in satisfying the Convention requirements, to penalise in Article 212 of the Aviation Law the infringement of air traffic regulations in force in the area where the flight takes place, as well as bans or restrictions on flights in the air space belonging to Poland, the formulation of which was dictated by military necessity or public security. Here, moreover, the same penalty of up to 5 years' imprisonment is imposed for crossing a state border by flying with an aircraft without the necessary authorisation or in breach of its conditions, as well as for failing to comply with instructions from state authorities or landing orders given by a domestic aircraft. Poland is also one of the contracting states to observe the provisions of the Convention for the Suppression of Unlawful Acts Against the Safety of Civil Aviation, which was drawn up in Montreal on 23 September 1971. This act, in its first article, includes among the offences the use of violence against a person on board an aircraft or in an airport if it is likely to endanger the safety of the aircraft. It also criminalises destroying or damaging an aircraft in such a way that renders it incapable of flight or which is likely to endanger its safety in flight as a result of knowingly communicating false information. Some of the criminal acts contained in Article 2 of the Montreal Convention are also characterised in the "criminal provisions" section of the Aviation Law. Their scope, both at convention and statutory levels, addresses the issue of damaging or rendering inoperable an airport or the facilities within it, including by means of any device, substance or weapon, thereby bringing danger to such a facility or only to the aircraft not in use, and causing disruption to the operation of the airport. The Polish legislator has decided that acts of this caliber will be punishable by imprisonment of up to 5 years. 


\section{Prohibited acts against air navigation in the Polish Penal Code}

Article 166 of the Penal Code satisfies the convention requirements that provide for air and water piracy, which manifests itself in the seizure of control of a vessel or aircraft. Issues relating to aircraft are governed by Article 2 of the Convention for the Suppression of Unlawful Seizure of Aircraft [8] drafted in The Hague on 16 December 1970. This provision requires states to classify the behaviour of a particular person as an offence punishable by a severe penalty. The act must consist of unlawfully taking possession of an aircraft or taking over control of an aircraft, whether with a threat to use or with the use of violence. The wording of Article 166 corresponds in its entirety to the specifics of the Convention standard stipulating that whoever, using a deceit or an act of violence against a person, or a threat to use such an act of violence, takes control of a ship or an aircraft, shall be subject to the penalty of imprisonment for 2 to 12 years. However, the Polish legislator decided to include here deceit as well as violence manifested in the form of a violent act committed against a person. Taking control consists of taking away the ability to control an aircraft/vessel by persons not authorised to do so. The perpetrator is most likely to take decisions about the direction of the flight/voyage personally, while deception, an act of violence against a person or a threat to commit such an act are unlawful actions which facilitate taking control. Deception is the use of insincere behaviour with the aim to gain approval for suggested actions, which would not have been achieved if it were not for the lie told to the victim. Another dimension of deception can be qualified as an effort to prevent a person from recognising the perpetrator's actions or acting in one's own defence due to the indisposition caused to the victim [20]. According to criminal law nomenclature, an act of violence against a person is synonymous with the use of physical violence of such intensity that it paralyses the resistance to it, and it is classified as an action violating human inviolability [17]. Such a violation has the consequence of endangering the health and life of the victim, which cannot be repelled in any way. These two elements satisfied together constitute the definition of "an act of violence against a person" which differs from the term "the use of violence" in that it carries more advanced bodily injury than mere violation of bodily integrity, and thus constitutes a qualified form of violence [1].

The literature and the judicature stress that the view expressed in the case law, considered as a legal principle, putting the equal sign between an act of violence against a person and the use of violence against a person is inadequate [21]. The offence typified in the first paragraph of Article 166 of the Penal Code has two qualified types, expressed respectively in paragraphs 2 and 3. The qualification of the former is to directly bring about danger to the life or health of many persons, while the latter envisages in its consequences the death of a human being or a severe injury to the health of many persons. As aptly noted, the effects expressed in the last paragraph constitute a qualified type compared to the previous one, since such an effect may arise only after, and only if a direct danger to the life or health of many persons is brought about [20]. The criminal conduct typified in the first paragraph of Article 167 of the Penal Code consists of placing on an aircraft a device or 
substance which is likely to endanger the safety of persons or property of significant value. This action may involve not only the delivery of such a substance on board an aircraft, but also placing equipment or apparatus on the outside of the aircraft. A danger brought about by such an act does not need to have a direct attribute, but only an actual threat to at least two persons [20]. It is clearly not an offence to place a substance or device to the transporting of which the aircraft is dedicated [13]. The property whose safety would be endangered is expressed in a specific amount, which, however, is not indicated in the provision concerned. Information on the value of property is provided by Article $115 \S 5$ of the Penal Code, in which the legislator decided to define property of a significant value as being at least PLN 200,000. Paragraph 2 of this article provides for destroying, damaging or rendering inoperable a navigation device or preventing its operation if the safety of persons is likely to be endangered [20]. Such a device is an instrument used for navigating an aircraft, which comprises the measurement of time, direction, speed and meteorological values. Preventing the operation of a device is defined as such a behaviour of the perpetrator which may manifest itself by restricting free access to that device, which access is normally given to a person with appropriate authorisations only [16].

Article 173 of the Penal Code criminalises the perpetrator of a disaster in land, water or air traffic, endangering the life or health of many people or property of great size. A disaster does not have to result from a breach of safety rules, which are nevertheless a fairly common cause of disasters, and the underlying cause is not relevant here [3]. A view which qualifies a breach of safety rules as an inherent prerequisite for the application of this provision should be regarded as unfounded [14]. The literature and the judicature have developed the concept of disaster as an event of a sudden and dangerous nature which causes a hazard in land, water or air traffic with widespread and paralysing consequences [22], which affect a certain number of people and pose a danger to property of great size [11]. In addition to a disaster, the article in question also refers to endangering the life or health of people, or property of great size, which entails narrowing down and clarifying this concept [14]. Property of great size is not a synonym for the concept of "property of great value", which is defined in Article 115 (6) of the Penal Code as the commensurability of at least one million PLN. In the discussed provision, the legislator decided that when defining the notion of property of great size, one should respect its extent and spaciousness, and not the value of the endangered object [5]. The doctrine is not unanimous as to what number is specified by the concept of "many people", while it has been determined that the lowest number should be between six and ten persons, but more and more often in the literature there is a predominance of the higher of these numbers [3]. J. Lachowski is of the opinion that if the perpetrator has brought about a disaster in which less than ten persons were endangered, and at the same time property not classified as "of great size" was endangered, it is unjustified to apply this provision [14]. The provision that follows appears to correspond in wording to the one commented on above, however, there are fundamental differences between the two.

An act under Article 174 falls into the category of offences posing threat to the safety, while the disaster that is articulated does not necessarily lead to the consequences described 
in the previous article. In order for an act to be considered as bringing about immediate danger, it is not necessary that property of a specific value or a specific number of persons be endangered [3]. The consequence of such an action is not the obligatory occurrence of a disaster [16], but provoking a situation which, regardless of human action, may at any time turn into a disaster [26]. As the Supreme Court has aptly pointed out, a safety-endangering event in land traffic does not need to be identified with a specific danger, whereas it is quite opposite in air traffic because of the reduced opportunity to cause perturbations during flight. Thus, each flight disturbance is attributed the attribute of a specific hazard which poses a direct threat of a disaster [28]. At the level of law provisions relating to offences committed also in air traffic, driving a motor vehicle while under the influence of alcohol or an intoxicant has also been typified. The judicature has given a definition to the term "motor vehicle" which, for aviation law purposes, may raise a number of doubts, since it is understood as any road or rail vehicle powered by an engine placed on it, a self-propelled machine or a moped, it being emphasised that the engine's cylinder capacity must exceed 50 cubic centimetres [29]. Help in adapting the interpretation of this definition to the needs of aviation law comes from a judgement of the Supreme Court, which held that the mere equipping of a vehicle with an engine, not necessarily used at a particular moment, makes such a machine a motor vehicle [29]. J. Lachowski is of the opinion that at the time the offence is committed, it is irrelevant whether the engine power is used or the source from which it draws its power, however, it is necessary that the vehicle is equipped with the engine required by the definition [14]. When the offender causes the vehicle to change its position under his/her control, both in terms of speed and its course, we are dealing with the act of driving [30]. The statement of the Supreme Court, which recognises that the person driving an aircraft is not only the crew present on board the aircraft, but also the flight manager who has a number of qualifications and competences in military aviation, is justified [27]. The legislator has decided that in such a case it is required that the driving takes place in the state of intoxication, which is defined in the Penal Code in Article 115 $\S 16$, in a specific amount of pure alcohol in human blood or in the air exhaled. These are units exceeding 0.5 per mille and 0.25 milligrams in 1 cubic decimetre of exhaled air, respectively.

\section{Criminal proceedings in extradition cases}

After a detailed analysis of the substantive criminal provisions contained in the Conventions, the Polish Penal Code and aviation law, it is worth briefly commenting on the proceedings concerning aviation offences. The judiciary acts on the basis of national criminal procedural law, without prejudice to the obligations imposed by international regulations [32]. It is worth noting at this point extradition, which is defined as surrendering a wanted person who has committed an offence to the services of a foreign country. Extradition may be applied to a citizen of a foreign state who is staying in the territory of a third state, thus excluding extradition of one's own national who commits a criminal act 
outside the territory of the home state. It can be implemented only if the surrendering state and the requesting state have concluded an international agreement to this effect [19]. The Tokyo Convention in its wording addresses the issue of extradition rather laconically, while stipulating the necessity of acknowledging that an offence committed on board a registered aircraft shall also be regarded as having been committed in the territory of the state of registration, and not only in the place where it occurred. The same article also points out that it is a misinterpretation of the provisions of the Tokyo Convention to hold that extradition is mandatory. The Hague Convention regulates the issues of extradition to a wider extent, stipulating that if a state within whose borders the offender is present decides, based on the circumstances, to detain the offender or to take other measures against them, the state is obliged to proceed in accordance with its national procedures and may only do so until criminal proceedings are instituted or extradition is effected. Criminal proceedings shall then take place in accordance with the national law of the detaining state and the possibility of extradition, as a result of an agreement between states, should be carried out following a request submitted by the state concerned. The Montreal Convention corresponds in its entirety to the provisions of the Hague Convention when addressing extradition issues, adding that where extradition is requested from a state detaining an offender by a state with which there is no extradition agreement in place, the latter may take into account the provisions of that Convention as a legal basis for the extradition.

\section{Summary}

Criminal law issues in aviation law cover mainly the occurrence of aviation accidents and incidents, and indicate how protection against such acts should operate. The discussed subject matter also includes the order and safety of air navigation, as well as the catalogue of punishable offences against the good order of air navigation, and the process of their prosecution. The basis for governing this subject matter are the international convention provisions, which are adopted in their entirety by national law systems, including in Poland. The Polish criminal law typifies criminal acts that endanger air navigation in Articles 166, 167, 173 and 174 of the Penal Code. These acts are crimes of effect (e.g. causing a plane crash) and, at the same time, acts that violate safety, which count as formal, inconsequential offences (e.g. unlawful seizure of control of an aircraft, which threatens the legal interest, but there need not be any effect resulting from the act or nonfeasance by the perpetrator). The application of these norms is supplemented by the application of Article 115, which contains a so-called "statutory glossary" indicating the understanding of the terms used in the specified provisions of law, such as "the state of intoxication", "a large-scale damage" or "a huge-scale damage". Those provisions fulfil the requirements of international agreements by which Poland is bound, and constitute part of the domestic law system as provisions of the commonly applicable law. 


\section{References}

1. Bigoszewski T.: Przemoc jako znamię strony przedmiotowej (in Polish), Cz. PKiNP 1997, nr 2, p. 19.

2. Bojarski T.: Komentarz do art. 113 Kodeksu karnego [in:] T. Bojarski (ed.) A. Michalska-Warias, J. Piórkowska-Flieger, M. Szwarczyk, Kodeks karny. Komentarz (in Polish), LEX nr 10269.

3. Budyn-Kulik M.: Komentarz aktualizowany do art. 173 Kodeksu karnego [in:] M. Mozgawa (ed.), M. Budyn - Kulik, P. Kozłowska-Kalisz, M. Kulik, Kodeks karny. Komentarz aktualizowany (in Polish), LEX nr 534444.

4. Grzegorczyk T.: Komentarz do art. 31 Kodeksu postępowania karnego [in:] T. Grzegorczyk, Kodeks postępowania karnego (in Polish). Tom I. Art. 1-467, LEX nr 428576.

5. Grzeszczyk W.: Najniższe miesięczne wynagrodzenie w rozumieniu art. $115 \S 5-8$ Kodeksu karnego i art. $53 \S 4$ Kodeksu karnego skarbowego (in Polish), PiP 2004, nr 4, p. 151.

6. Konarska-Wrzosek V.: Komentarz do art. 113 Kodeksu karnego [in:] J. Lachowski, Komentarz do art. 173 Kodeksu karnego [in:] V. Konarska-Wrzosek (ed.), A. Lach, J. Lachowski, T. Oczkowski, I. Zgoliński, A. Ziółkowska, Kodeks karny. Komentarz (in Polish), LEX nr 10437.

7. Konwencja o międzynarodowym lotnictwie cywilnym, podpisana w Chicago dnia 7 grudnia 1944 r. - Konwencja chicagowska (in Polish) (Dz. U z 1959 r. Nr 35, poz. 212, z późn. zm.).

8. Konwencja o zwalczaniu bezprawnego zawładnięcia statkami powietrznymi z dnia 16 grudnia 1970 r. podpisana w Hadze (in Polish) (Dz. U. 1972 r. Nr 25, poz. 181).

9. Konwencja o zwalczaniu bezprawnych czynów skierowanych przeciwko bezpieczeństwu lotnictwa cywilnego, sporządzona w Montrealu 23 września $1971 \mathrm{r}$. (in Polish) (Dz. U. 1976 Nr 8 poz. 37).

10. Konwencja w sprawie przestępstw i niektórych czynów popełnionych na pokładzie statków powietrznych z dnia 14 września 1963 r. podpisana w Tokio (in Polish) (Dz. U z 1971 r. Nr 15, poz. 147).

11. Kotowski W.: Glosa do wyroku sądu apelacyjnego z dnia 10 grudnia 2014 r. (in Polish), sygn. akt II AKa 383/14, LEX nr 272915.

12. Kozłowska-Kalisz P.: Komentarz aktualizowany do art. 5 Kodeksu karnego [in:] M. Mozgawa (ed.) M. Budyn-Kulik, P. Kozłowska-Kalisz, M. Kulik, Kodeks karny. Komentarz aktualizowany (in Polish), LEX nr 534247.

13. Kulik M.: Komentarz aktualizowany do art.165 Kodeksu karnego [in:] M. Mozgawa (ed.), M. Budyn-Kulik, P. Kozłowska-Kalisz, M. Kulik, Kodeks karny. Komentarz aktualizowany (in Polish), LEX nr 534444.

14. Lachowski J.: Komentarz do art. 173 Kodeksu karnego [in:] V. Konarska-Wrzosek (ed.), A. Lach, J. Lachowski, T. Oczkowski, I. Zgoliński, A. Ziółkowska, Kodeks karny. Komentarz (in Polish), LEX nr 10437. 
15. Myszona-Kostrzewa K., Z. Galicki (ed.): Pięćdziesiąt lat konwencji tokijskiej bezpieczeństwo żeglugi lotniczej z perspektywy przestrzeni powietrznej i kosmicznej. Księga dedykowana Profesorowi Markowi Żyliczowi (in Polish), Warszawa 2014, p. 238.

16. Piórkowska-Flieger J.: Komentarz do art. 167 Kodeksu karnego [in:] T. Bojarski (ed.) A. Michalska-Warias, J. Piórkowska-Flieger, M. Szwarczyk, Kodeks karny. Komentarz (in Polish), LEX nr 10269.

17. Postanowienie SN z dnia 16 marca 1999 r. (in Polish), I KZP 32/98.

18. Raglewski J.: Komentarz do art. 113 Kodeksu karnego [in:] W. Wróbel (ed), A. Zoll (ed.) i inni, Kodeks karny. Część ogólna. Tom I. Część II. Komentarz do art. 53 - 116 (in Polish), LEX nr 10419.

19. Skrzydło W.: Komentarz do art. 55 Konstytucji Rzeczypospolitej Polskiej [in:] W. Skrzydło, Konstytucja Rzeczypospolitej Polskiej. Komentarz (in Polish), LEX nr 8778.

20. Stefański R.A.: Komentarz do art.166 Kodeksu karnego [in:] M. Filar (ed.) i in. Kodeks karny. Komentarz (in Polish), LEX nr 10366.

21. Uchwała składu 7 sędziów SN z 17 grudnia 2008 r. (in Polish), I KZP 27/08.

22. Uchwała SN z dnia 28 lutego 1975 r. (in Polish), sygn. akt V KZP 2/74.

23. Ustawa z dnia 12 października 1990 r. o ochronie granicy państwowej (in Polish) (Dz. U. 2019 poz. 1776).

24. Ustawa z dnia 6 czerwca 1997 r. - Kodeks karny (in Polish) (Dz. U. z 2020 r. poz. 1444).

25. Ustawa z dnia 6 czerwca 1997 r. Kodeks postępowania karnego (in Polish) (Dz. U. 2020 poz. 30$)$.

26. Wyrok SN z 21 maja 1974 r. (in Polish), sygn. akt III KR 407/73.

27. Wyrok SN z 29 stycznia 1972 r. (in Polish), sygn. akt Rw 1532/71.

28. Wyrok SN z dnia 25 lutego 1971 r. (in Polish), I KR 225/70.

29. Wyrok SN z dnia 4 lutego 1993 r. (in Polish), sygn. akt III KRN 254/92.

30. Wyrok SO w Kielcach z dnia 10 grudnia 2013 r. (in Polish), IX Ka 1523/13, LEX nr 1717640 .

31. Zoll A.: Komentarz do art. 5 Kodeksu karnego [in:] W. Wróbel (ed.), A. Zoll (red.): Kodeks karny. Część ogólna. Tom I. Część I. Komentarz do art. 1-52 (in Polish), LEX nr 10420.

32. Żylicz M.: Prawo lotnicze międzynarodowe, europejskie, krajowe (in Polish), ed. 2, Lexis Nexis, Warszawa 2011. 


\section{LOTNICZE PRAWO KARNE. REGULACJE KONWENCJI TOKIJSKIEJ ORAZ KODEKSU KARNEGO W CELU PRZECIWDZIALANIA AKTOM TERRORU}

\section{Wprowadzenie}

W doktrynie pojęcie lotniczego prawa karnego wykształciło się jako wszelkie normy prawne regulujące proces ścigania oraz nakładania kary za popełnione przestępstwa i wykroczenia, które godzą w dobro, jakim jest porządek żeglugi powietrznej. Penalizacja czynów przestępnych przeciwko żegludze powietrznej może wiązać się również z troską o zdrowie i życie ludzkie, a także o mienie [32]. Przepisy te, będące podłożem lotniczego prawa karnego, w głównej mierze regulowane są przez jest tzw. system tokijsko-haskomontrealski, obejmujący trzy konwencje międzynarodowe uzgodnione pod pieczą ICAO (International Civil Aviation Organization), które wiążą wszystkie państwa będące stronami tego porozumienia [15]. Konwencja w sprawie przestępstw i niektórych czynów popełnionych na pokładzie statków powietrznych [10], sporządzona w Tokio dnia 14 września 1963 r., zobowiązuje państwa umawiające się do wykonywania jurysdykcji w przypadku przestępstw popełnionych na pokładzie statku państwa rejestracji. Należy podjąć wszelkie możliwe środki mające na celu wyznaczenie własnej właściwości jako państwa, w którym statek zarejestrowano, w wypadku dokonania czynu przestępnego na pokładzie statku państwa rejestracji. W następstwie wyznaczenia właściwości, podejmując działania śledcze, konieczne jest uwzględnienie bezpieczeństwa oraz interesów żeglugi powietrznej, a ponadto niewszczynanie bezpodstawnych działań powodujących zakłócenia dla statku powietrznego. Państwo, które nie jest państwem rejestracji, w celu wykonania swojej jurysdykcji, poza przypadkami wskazanymi w konwencji, nie jest uprawnione do paraliżowania lotu statku powietrznego. Wyjątkowe przypadki, wskazane w artykule 4, odnoszą się głównie do ochrony bezpieczeństwa zainteresowanego państwa. 


\section{Lotnicze prawo karne - międzynarodowe i państwowe regulacje ścigania przestępstw i wykroczeń w lotnictwie}

Posiłkowanie się polskim ustawodawstwem karnym ma miejsce wówczas, kiedy czyn zabroniony został popełniony na terytorium RP, a także na polskim statku wodnym lub powietrznym, chyba że umowa międzynarodowa, której Rzeczpospolita Polska jest stroną, stanowi inaczej. Kodeks karny [24] nie ukształtował pojęcia terytorium RP, jednakże ustawa z dnia 12 października 1990 r. o ochronie granicy państwowej [23] nadała mu definicję określającą ten obszar. Terytorium polskie rozumiane jest jako obszar objęty granicami państwowymi, oddzielającymi terytorium Rzeczypospolitej Polskiej od terytoriów innych państw i morza pełnego oraz wód wewnętrznych i pasa morskiego wód terytorialnych oraz przestrzeń powietrzną nad tym obszarem i wnętrze ziemi pod nim. Przestrzeń powietrzną nad terytorium RP zakreśla granica przestrzeni kosmicznej, która ma swój początek w miejscu, gdzie przebiegają najniższe orbity sztucznych satelitów ziemi, co stanowi ok. 90 km [31]. Zastosowanie polskiego Kodeksu karnego rozszerza się na polskie, czyli zarejestrowane w Polsce, statki powietrzne oraz wodne, które nie tworzą terytorium RP [12]. Zgodnie z art. 31 Kodeksu postępowania karnego [25] sądem właściwym do rozpoznania sprawy jest ten sąd, w którego okręgu dokonano przestępstwa. Jest to obowiązek rozpoznania sprawy przez sąd, ze względu na lokalizację zdarzenia, tam gdzie sprawca działał lub zaniechał działania. W wypadku jego popełnienia na polskim statku wodnym lub powietrznym właściwym sądem jest sąd macierzystego portu statku, jeżeli nie ma możliwości zastosowania wcześniej wskazanej reguły, z powodu pozostawania statku poza granicami RP [4].

M. Żylicz zwraca uwagę, by na płaszczyźnie lotniczego prawa karnego wyróżnić przestępstwa międzynarodowe, których ściganie jest obligatoryjne dla państw będących stronami odpowiednich konwencji międzynarodowych, które po odpowiednim wdrożeniu są elementem krajowego porządku prawnego oraz przestępstwa stypizowane przez ustawodawstwa krajowe oraz wykroczenia penalizowane przez wewnętrzne porządki prawne [32]. Rozpoczynając rozważania na temat pierwszej z tych kategorii przestępstw oraz ich katalogu, warto ogólnie przybliżyć instytucję delicta iuris gentium, tłumaczoną na wiele sposobów, tj. przestępstwa prawa międzynarodowego, przestępstwa konwencyjne albo przestępstwa prawa narodów. Przestępstwa wyrażone w umowach międzynarodowych umożliwiają, a zarazem zobowiązują wszystkich sygnatariuszy umowy do ich ścigania oraz karania. Katalog czynów nie jest enumeratywny, a jako przykłady można wymienić terroryzm lotniczy, uczynienie z załogi statku powietrznego zakładników, piractwo morskie [2]. Pacyfikacja tych bezprawnych aktów nie leży w gestii tylko jednego państwa, a jest obowiązkiem całej społeczności międzynarodowej, ze względu na zagrożenie dla całej ludzkości [18].

Zasadę represji wszechświatowej ustawodawca zawarł w polskim Kodeksie karnym, który $\mathrm{w}$ art. 113 stanowi, że niezależnie od przepisów obowiązujących w miejscu popełnienia przestępstwa, ustawę karną polską stosuje się do obywatela polskiego oraz cudzoziemca, którego nie postanowiono wydać, w razie popełnienia przez niego za granicą 
przestępstwa, do którego ścigania Rzeczpospolita Polska jest zobowiązana na mocy umowy międzynarodowej, lub przestępstwa określonego w Rzymskim Statucie Międzynarodowego Trybunału Karnego (MTK), sporządzonym w Rzymie dnia 17 lipca 1998 r. (Dz. U. z 2003 r. poz. 708). Bez znaczenia jest obywatelstwo sprawcy, jak i również miejsce popełnienia przestępstwa, gdyż zasada represji wszechświatowej umożliwia ściganie, które nie jest ograniczone zasadą terytorialności. RP podpisując traktaty międzynarodowe ma obowiązek, zgodnie z własnym ustawodawstwem karnym, postawić sprawcę przed polskim sądem, w sytuacji jeśli nie zdecydowała się na wydanie takiej osoby obcemu państwu, ani żadne państwo nie przedstawiło wniosku o takie wydanie [6]. Czyny spenalizowane w Statucie MTK stanowią dopełnienie katalogu przestępstw określonych traktatami międzynarodowymi, które nie maja potrzeby być wprowadzane do wewnętrznych systemów prawa karnego. Taki zabieg ma za zadanie zabezpieczyć polskich obywateli, którzy dokonali czynu przestępnego poza terytorium RP oraz w przypadku których nie został urzeczywistniony wymóg podwójnej karalności, a na Polskę nie nałożono obowiązku ich ścigania [2]. Osoby podejrzane o popełnienie przestępstw zamieszczonych w statucie MTK są przede wszystkim poddawane pod sądownictwo krajowe, z tego powodu, że jurysdykcja MTK nosi przymiot uzupełniającego wewnętrzne systemy prawne. Czyny te klasyfikowane są jako najpoważniejsze zbrodnie międzynarodowe, do których zaliczyć można ludobójstwo, agresję, zbrodnie wojenne oraz przeciwko ludzkości, nieulegające przedawnieniu [6].

W tym miejscu należy przybliżyć wybrane przestępstwa międzynarodowe zawarte w konwencji chicagowskiej [7] oraz montrealskiej [9], których część została wiernie odwzorowana przez polski porządek prawny, a niektóre z nich potraktowano szczątkowo albo odbiegająco od konwencyjnych definicji. Artykuł 3 bis konwencji sporządzonej w Chicago porusza kwestię zakłócania suwerenności państwa na swoim terytorium podniebnym. Konsekwencją uznania, że każda strona konwencji jest zobowiązana do zaniechania podejmowania działań $\mathrm{z}$ użyciem broni $\mathrm{w}$ stosunku do obcego statku powietrznego, nie można uznać za wymagane powstrzymanie się od jakichkolwiek działań w wypadku przelotu statku bez wymaganego pozwolenia lub wykorzystanemu w celu sprzecznym z ustaleniami państw. Takie państwo, w wypadku braku pozwolenia, może podjąć interwencję polegająca na żądaniu lądowania w konkretnym porcie lotniczym lub wystosowaniu innych dyspozycji służących pohamowaniu bezprawnego postępowania, które są współmierne z przyjętymi zasadami społeczności międzynarodowej, a każdy statek dopuszczających się tego czynu ma obowiązek podporządkowania się do tych wytycznych państwa. Na państwa umawiające się nałożono obowiązek uregulowania tej materii w taki sposób, aby nałożona kara była restrykcyjna i współmierna do dokonanego czynu, a analiza każdego z nich została podana do wiadomości właściwym organom. Rozwinięciem obowiązków statku znajdującego się w przestrzeni powietrznej obcego państwa jest art. 12, stanowiący o respektowaniu reguł i ustawodawstwa w zakresie lotu i operowania samolotem obowiązujących na konkretnym terytorium. Przepisy te powinny być odzwierciedlane w krajowych porządkach prawnych w sposób bardzo precyzyjny i rzetelny oraz wieloaspektowy. Polski ustawodawca zdecydował, czyniąc zadość przepisom 
konwencyjnym, o spenalizowaniu w art. 212 prawa lotniczego naruszenia przepisów dotyczących ruchu lotniczego obowiązujących w obszarze, w którym lot się odbywa, a także zakazów lub ograniczeń lotu w przestrzeni podniebnej należącej do Polski, których sformułowanie zostało podyktowane koniecznością wojskową lub bezpieczeństwem publicznym. W tym miejscu ponadto, tej samej karze - do 5 lat pozbawienia wolności poddano przekroczenie granicy państwowej, wykonując lot przy użyciu statku powietrznego, bez koniecznego zezwolenia lub z naruszeniem jego warunków, a także niezastosowanie się do dyspozycji organów państwa czy polecenia lądowania wydanego przez krajowy statek powietrzny. Polska jest także jednym z państw umawiających się do przestrzegania przepisów Konwencji o zwalczaniu bezprawnych czynów skierowanych przeciwko bezpieczeństwu lotnictwa cywilnego, która została sporządzona w Montrealu 23 września 1971 r. Akt ten, w artykule pierwszym, do przestępstw zalicza między innymi stosowanie przemocy wobec kogokolwiek, kto znajduje się na pokładzie statku lub w porcie lotniczym, a działaniem tym może sprowadzić niebezpieczeństwo na ten statek powietrzny. Spenalizowano również doprowadzanie działaniem niszczycielskim do niezdolności poruszania się statku albo zagrożenia jego bezpieczeństwa w locie w wyniku świadomego przekazania fałszywych informacji. Niektóre czyny przestępne zawarte w art. 2 konwencji montrealskiej zostały również scharakteryzowane w rozdziale ,przepisy karne” ustawy prawo lotnicze. Ich zakres, zarówno na płaszczyźnie konwencyjnej, jak i ustawowej, traktuje o uszkadzaniu lub spowodowaniu niezdolności użytkowania lotniska lub urządzeń w jego obrębie, a także za pomocą jakiegokolwiek urządzenia, substancji lub broni sprowadza niebezpieczeństwo na taka placówkę lub tylko na statki powietrzne niebędące w użyciu, powodując zakłócenia w działaniu lotniska. Polski prawodawca zdecydował, że czyny takiego kalibru będą zagrożone kara pozbawienia wolności do lat 5.

\section{Czyny zabronione przeciwko żegludze lotniczej w polskim Kodeksie karnym}

Artykuł 166 Kodeksu karnego czyni zadość wymogom konwencyjnym, które stanowią o piractwie powietrznym i wodnym, które przejawia się w przejęciu kontroli nad statkiem wodnym czy powietrznym. Zagadnienia związane ze statkami powietrznymi reguluje art. 2 Konwencji o zwalczaniu bezprawnego zawładnięcia statkami powietrznymi [8], której opracowanie miało miejsce w Hadze 16 grudnia 1970 r. Przepis ten nakłada na państwa obowiązek zakwalifikowania postępowania konkretnej osoby jako przestępstwo sankcjonowane dotkliwą karą. Działanie to musi polegać na bezprawnym, z groźbą użycia przemocy lub jej zastosowaniem, zawładnięciem statkiem powietrznym lub przejęciem nad nim kontroli. Brzmienie artykułu 166 w całej rozciągłości odpowiada specyfice normy konwencyjnej, stanowiąc że kto, stosując podstęp albo gwałt na osobie lub groźbę bezpośredniego użycia takiego gwałtu, przejmuje kontrolę nad statkiem wodnym lub powietrznym, podlega karze pozbawienia wolności od lat 2 do 12 . Jednakże polski 
ustawodawca zdecydował, aby w płaszczyźnie takiego działania znalazł się także podstęp, a przemoc objawiała się również w postaci gwałtu. Przejęcie kontroli polega na odebraniu możliwości kontroli nad statkiem przez osoby niemające uprawnienia do dokonywania tego rodzaju czynności. Sprawca najczęściej osobiście podejmuje decyzje dotyczące kierunku rejsu, a podstęp, gwałt na osobie lub groźba bezpośredniego użycia gwałtu to bezprawne działania dające sposobność przejęcia kontroli. Podstęp stanowi zastosowanie nieszczerego postępowania, które ma na celu uzyskanie aprobaty na zasugerowane czynności, która nie zostałaby osiągnięta, gdyby wobec pokrzywdzonego nie dopuszczono się kłamstwa. Drugi wymiar podstępu można zakwalifikować jako zabieg uniemożliwiający rozpoznanie własnych czynów lub występowanie we własnej obronie ze względu na niedyspozycję w jaką pokrzywdzony został wprawiony [20]. Według nomenklatury karnoprawnej gwałt jest synonimem użycia przemocy fizycznej o takiej intensyfikacji, która paraliżuje stawiany jej opór, zaliczająca się do działań stanowiących naruszenie nietykalności człowieka [17]. Takie naruszenie rodzi konsekwencje w postaci zagrożenia dla zdrowia i życia pokrzywdzonego, które w żaden sposób nie mogą zostać odparte. Te dwa elementy spełnione łącznie stanowią definicję pojęcia gwałtu, który różni się od terminu użycia przemocy tym, że niesie za sobą bardziej zaawansowane obrażenia ciała niż samo naruszenie jego integralności, a tym samym stanowi kwalifikowaną formę użycia przemocy [1].

W literaturze i judykaturze podkreśla się, iż nieadekwatny jest wyrażony w orzecznictwie pogląd, uznany za zasadę prawną, stawiający znak równości między gwałtem na osobie, a użyciem przemocy wobec osoby [21]. Przestępstwo stypizowane w paragrafie pierwszym art. $166 \mathrm{KK}$ posiada dwa typy kwalifikowane, wyrażone odpowiednio w paragrafie 2 oraz 3 . Kwalifikacja pierwszego z nich polega na sprowadzeniu bezpośredniego niebezpieczeństwa dla życia lub zdrowia wielu osób, zaś drugie w swoich konsekwencjach przewiduje śmierć człowieka lub ciężki uszczerbek na zdrowiu wielu osób. Jak trafnie zauważono, skutki wyrażone w ostatnim z paragrafów stanowią typ kwalifikowany w porównaniu do wcześniejszego, gdyż taki skutek może pojawić się dopiero wówczas i tylko w następstwie sprowadzenia bezpośredniego niebezpieczeństwa dla życia czy zdrowia wielu osób [20]. Zachowanie przestępne stypizowane w paragrafie pierwszym art. 167 Kodeksu karnego polega na umieszczeniu na statku powietrznym urządzenia lub substancji zagrażającej bezpieczeństwu osób lub mieniu znacznej wartości. Działanie to może polegać nie tylko na dostarczeniu na pokład statku takiej substancji, ale również przymocowanie sprzętu czy aparatury po zewnętrznej stronie statku. Sprowadzone taką czynnością niebezpieczeństwo nie wymaga posiadania przymiotu bezpośredniego, a tylko rzeczywistego grożącego co najmniej dwóm osobom [20]. Przestępstwa nie stanowi tu oczywiście ulokowanie substancji lub urządzenia, do którego przewozu dany statek jest zadedykowany [13]. Mienie, którego bezpieczeństwo zostałoby zagrożone zostało wyrażone w konkretnej wysokości, która jednakże nie została wyartykułowana w przepisie. Informację o wartości mienia dostarcza nam art. $115 \S 5 \mathrm{KK}$, w którym ustawodawca zdecydował się zdefiniować mienie znacznej wartości jako współmierność co najmniej 200000 zł. Paragraf 2 tego artykułu stanowi o niszczeniu, uszkadzaniu lub uczynieniu niezdatnym do użytku urządzenia nawigacyjnego albo uniemożliwieniu jego obsługi, jeżeli 
może to zagrażać bezpieczeństwu osób [20]. Urządzeniem takim jest taki przyrząd, który służy realizowaniu nawigacji statku powietrznego, w której płaszczyźnie mieści się pomiar czasu, kierunku czy prędkości oraz wartości meteorologicznych. Uniemożliwienie obsługi definiuje się jako takie zachowanie sprawcy, które może objawiać się zatrzymaniu wolnego dostępu do tego urządzenia, do którego posiada tylko osoba legitymująca się odpowiednimi uprawnieniami [16].

Artykuł 173 Kodeksu karnego penalizuje sprawcę katastrofy w ruchu lądowym, wodnym lub powietrznym, zagrażającej życiu lub zdrowiu wielu osób albo mieniu w wielkich rozmiarach. Katastrofa nie musi wynikać z naruszenia reguł bezpieczeństwa, które mimo wszystko są dość częstą przyczyną nastąpienia katastrofy, a jej podłoże nie jest tutaj relewantne [3]. Za bezzasadny należy uznać pogląd, który kwalifikuje naruszenie zasad bezpieczeństwa jako immanentną przesłankę stosowania tego przepisu [14]. Literatura i orzecznictwo wykształciły pojęcie katastrofy jako zdarzenia o charakterze nagłym i groźnym, które powoduje zagrożenie w ruchu lądowym, wodnym lub powietrznym pociągającym za sobą rozległe i porażające konsekwencje [22], które dotykają określoną liczbę osób oraz niosą niebezpieczeństwo dla mienia w wielkich rozmiarach [11]. Komentowany artykuł poza katastrofą dodatkowo stanowi o zagrożeniu dla życia lub zdrowia bądź mienia w wielkich rozmiarach, co pociąga za sobą fakt, iż pojęcie to zostało zawężone i doprecyzowane [14]. Mienie w wielkich rozmiarach nie stanowi synonimu pojęcia mienia wielkiej wartości, które zostało zdefiniowane w art. 115 par. 6 Kodeksu karnego jako współmierność co najmniej miliona złotych. W komentowanym przepisie ustawodawca zadecydował, że przy definiowaniu pojęcia mienia w wielkich rozmiarach, należy respektować jego zasięg oraz przestronność, a nie wartość majątkową zagrożonego przedmiotu [5]. W doktrynie nie zostało jednomyślnie uszczegółowione jaką liczbę uściśla pojęcie wielu osób, natomiast wyznaczono, że najniższą jej wartością powinny być ramy od sześciu do dziesięciu osób, jednakże coraz częściej w literaturze można spotkać przewagę tej wyższej miary [3]. J. Lachowski stoi na stanowisku, iż jeśli sprawca sprowadził katastrofę, podczas której mniej niż dziesięć osób zostało poddanych niebezpieczeństwu, a równocześnie zostało zagrożone mienie, które nie zostało sklasyfikowane jako wielkich rozmiarów, bezzasadne jest stosowanie tego przepisu [14]. Następujący po tym artykule przepis wydaje się w swoim brzmieniu odpowiadać wcześniej komentowanemu, jednakże między nimi należy zauważyć podstawowe odrębności.

Czyn z art. 174 zalicza się do kategorii przestępstw z narażenia na niebezpieczeństwo, a katastrofa, która została wyartykułowana nie musi zmierzać do zaistnienia konsekwencji opisanych w poprzednim artykule. Nie jest konieczne do zaliczenia danego czynu jako sprowadzenia bezpośredniego niebezpieczeństwa wystąpienie zagrożenia mienia o określonej wartości ani konkretnej liczby osób [3]. Skutkiem takiego działania nie jest obligatoryjne wystąpienie katastrofy [16], ale sprowokowanie sytuacji, która niezależnie od działań człowieka, w dowolnym momencie może przeobrazić się w katastrofę [26]. Jak trafnie podniósł Sąd Najwyższy, w ruchu lądowym zdarzenie grożące niebezpieczeństwem nie musi być identyfikowane z konkretnym niebezpieczeństwem, natomiast sytuacja jest zgoła odmienna $\mathrm{W}$ ruchu powietrznym, $\mathrm{z}$ powodu zredukowania sposobności 
spowodowania perturbacji podczas lotu. Tak więc każdemu zaburzeniu lotu przypisywany jest przymiot niebezpieczeństwa konkretnego, grożącego bezpośrednio katastrofą [28]. Na płaszczyźnie przepisów odnoszących się do przestępstw popełnionych także w ruchu powietrznym stypizowano również prowadzenie pojazdu mechanicznego w stanie nietrzeźwości lub pod wpływem środka odurzającego. Orzecznictwo nadało pojęciu pojazdu mechanicznego definicję, która na gruncie prawa lotniczego może nasuwać wiele wątpliwości, albowiem jest to każdy pojazd drogowy lub szynowy napędzany umieszczonym na nim silnikiem, maszyna samobieżna oraz motorower, przy czym podkreśla się, że pojemność skokowa silnika powinna przekraczać 50 centymetrów sześciennych [29]. Z pomocą $\mathrm{w}$ dostosowaniu wykładni tej definicji do potrzeb prawa lotniczego śpieszy wyrok Sądu Najwyższego, który uznał, że samo zaopatrzenie pojazdu w silnik, niekoniecznie używany w konkretnej chwili, czyni taką maszynę pojazdem mechanicznym [29]. J. Lachowski stoi na stanowisku, że w czasie popełnienia przestępstwa irrelewantne jest wykorzystywanie siły silnika, ani jego źródło, z którego czerpie energię, jednakże konieczne jest, aby pojazd, który w swoim wyposażeniu posiadał wymagany definicją silnik [14]. Kiedy sprawca powoduje, że pod jego kontrolą zarówno prędkościową, jak również jego kursem, pojazd zmienia miejsce swojego położenia mamy do czynienia z prowadzeniem pojazdu [30]. Zasadna jest konstatacja Sądu Najwyższego, uznająca za osobę prowadzącą samolot, nie tylko załogę przebywającą w samolocie, ale także kierownika lotów posiadającego szereg kwalifikacji i kompetencji z zakresu lotnictwa wojskowego [27]. Ustawodawca zdecydował, iż w tym przypadku wymagane jest, aby prowadzenie pojazdu odbywało się w stanie nietrzeźwości, który został zdefiniowany w Kodeksie karnym w art. $115 \S 16$, w konkretnej ilości czystego alkoholu we krwi człowieka albo w wydychanym powietrzu. Odpowiednio są to jednostki przekraczające 0,5 promila oraz 0,25 miligramów w 1 decymetrze sześciennym wydychanego powietrza.

\section{Postępowanie karne w sprawach o ekstradycje}

Po szczegółowej analizie materialnych przepisów karnych zawartych w konwencjach, polskim Kodeksie karnym oraz w prawie lotniczym wartym krótkiego skomentowania jest postępowanie w sprawie przestępstw lotniczych. Wymiar sprawiedliwości podejmuje działania na podstawie krajowych przepisów o postępowaniu karnym, nie uchybiając obowiązkom nałożonym poprzez regulacje międzynarodowe [32]. Warto w tym miejscu zwrócić uwagę na ekstradycję, którą definiuje się jako wydanie służbom obcego państwa osoby, która popełniła przestępstwo i jest przez nie poszukiwanym. Ekstradycja może być zastosowana w stosunku do osoby legitymującej się obywatelstwem obcego państwa, która znajduje się na obszarze państwa trzeciego, a więc wykluczona jest ekstradycja własnego obywatela popełniającego czyn przestępny poza terytorium ojczyzny. Ma ona możliwość bycia urzeczywistnioną tylko w wypadku, gdy państwo wydające oraz wnoszące o ekstradycję zawarły stanowiąca w tym zakresie odpowiednią umowę międzynarodową [19]. Konwencja tokijska w swoim brzmieniu dość lakonicznie odniosła się do zagadnienia 
ekstradycji, przy którym konstytuuje o konieczności uznania, że przestępstwo popełnione na pokładzie zarejestrowanego statku powietrznego jest uznawane za dokonane także na terytorium Państwa rejestracji, a nie tylko w miejscu, w którym się wydarzyło. W tym samym artykule, zaznaczono również, że błędną interpretacją przepisów Konwencji tokijskiej jest wykładnia prowadząca do uznania, że ekstradycja jest obligatoryjna. Konwencja haska szerzej unormowała zagadnienia związane z ekstradycją, stanowiąc, że jeśli państwo, w granicach którego przebywa sprawca przestępstwa, na podstawie okoliczności zdecyduje o zatrzymaniu przestępcy lub o zastosowaniu wobec niego innych środków, zobligowane jest do postępowania zgodnie z krajowymi procedurami i może trwać tylko do rozpoczęcia postępowania karnego lub urzeczywistnienia ekstradycji. Postępowanie karne odbywa się wówczas zgodnie z przepisami krajowymi państwa zatrzymującego, a możliwość ekstradycji, będąca wynikiem umowy miedzy państwami, powinna zostać przeprowadzona po złożeniu wniosku przez zainteresowane państwo. Konwencja Montrealska w całej swej rozciągłości przy problematyce związanej z ekstradycją odpowiada postanowieniom zawartym w Konwencji haskiej, ponadto dodając, że w przypadku zwrócenia się do państwa zatrzymującego przestępcę o ekstradycję przez takie państwo, z którym nie została zawarta umowa ekstradycyjna, może ono uwzględnić przepisy tej konwencji jako podstawę prawną ekstradycji.

\section{Podsumowanie}

Zagadnienia karnoprawne w prawie lotniczym w głównej mierze obejmują zaistniałe wypadki i incydenty lotnicze oraz wskazują jak powinna przebiegać ochrona przed takimi aktami. W omawianej tematyce mieści się również porządek i bezpieczeństwo żeglugi powietrznej, a także katalog penalizowanych czynów godzących w dobro, jakim jest porządek żeglugi powietrznej, oraz proces ich ścigania. Podstawę uregulowań tej tematyki stanowią przepisy konwencyjne o zasięgu międzynarodowym, które w całej rozciągłości są przyjmowane przez krajowe porządki prawne, w tym także przez Polskę. Polska ustawa karna typizuje czyny przestępne zagrażające żegludze powietrznej w art. 166, 167, 173 i 174 Kodeksu karnego, będące zarówno czynami o charakterze przestępstw skutkowych (np. spowodowanie katastrofy lotniczej), jak i czynów naruszających bezpieczeństwo, które to są przestępstwami formalnymi, bezskutkowymi (np. bezprawne przejęcie kontroli nad statkiem powietrznym, które to zagraża dobru prawnemu, jednakże nie musi nastąpić żaden skutek wynikający z działania lub zaniechania sprawcy). Stosowanie niniejszych norm uzupełnione jest stosowaniem art. 115, w którym znajduje się tzw. słowniczek ustawowy, wskazujący rozumienie wyrażeń zawartych w określonych normach prawnych, takich jak „stan nietrzeźwości”, „szkoda dużych rozmiarów”, a także „szkoda wielkich rozmiarów”. Przepisy te czynią zadość wymaganiom umów międzynarodowych, którymi Polska jest związana, stanowiąc je częścią krajowego porządku prawnego jako przepisy prawa powszechnie obowiązującego. 


\section{Literatura}

1. Bigoszewski T.: Przemoc jako znamię strony przedmiotowej, Cz. PKiNP 1997, nr 2, s. 19.

2. Bojarski T.: Komentarz do art. 113 Kodeksu karnego [w:] T. Bojarski (red.) A. Michalska-Warias, J. Piórkowska-Flieger, M. Szwarczyk, Kodeks karny. Komentarz, LEX nr 10269.

3. Budyn-Kulik M.: Komentarz aktualizowany do art. 173 Kodeksu karnego [w:] M. Mozgawa (red.), M. Budyn-Kulik, P. Kozłowska-Kalisz, M. Kulik, Kodeks karny. Komentarz aktualizowany, LEX nr 534444.

4. Grzegorczyk T.: Komentarz do art. 31 Kodeksu postępowania karnego [w:] T. Grzegorczyk, Kodeks postępowania karnego. Tom I. Art. 1-467, LEX nr 428576.

5. Grzeszczyk W.: Najniższe miesięczne wynagrodzenie w rozumieniu art. $115 \S 5-8$ Kodeksu karnego i art. 53 § 4 Kodeksu karnego skarbowego, PiP 2004, nr 4, p. 151.

6. Konarska-Wrzosek V.: Komentarz do art. 113 Kodeksu karnego [w:] J. Lachowski, Komentarz do art. 173 Kodeksu karnego [w:] V. Konarska-Wrzosek (red.), A. Lach, J. Lachowski, T. Oczkowski, I. Zgoliński, A. Ziółkowska, Kodeks karny. Komentarz, LEX nr 10437.

7. Konwencja o międzynarodowym lotnictwie cywilnym, podpisana w Chicago dnia 7 grudnia 1944 r. - Konwencja chicagowska (Dz. U z 1959 r. Nr 35, poz. 212, z późn. $\mathrm{zm}$.).

8. Konwencja o zwalczaniu bezprawnego zawładnięcia statkami powietrznymi z dnia 16 grudnia 1970 r. podpisana w Hadze (Dz. U. 1972 r. Nr 25, poz. 181).

9. Konwencja o zwalczaniu bezprawnych czynów skierowanych przeciwko bezpieczeństwu lotnictwa cywilnego, sporządzona w Montrealu 23 września $1971 \mathrm{r}$. (Dz. U. $1976 \mathrm{Nr} 8$ poz. 37).

10. Konwencja w sprawie przestępstw i niektórych czynów popełnionych na pokładzie statków powietrznych z dnia 14 września 1963 r. podpisana w Tokio (Dz. U z 1971 r. Nr 15, poz. 147).

11. Kotowski W.: Glosa do wyroku sądu apelacyjnego z dnia 10 grudnia 2014 r., sygn. akt II AKa 383/14, LEX nr 272915.

12. Kozłowska-Kalisz P.: Komentarz aktualizowany do art. 5 Kodeksu karnego [w:] M. Mozgawa (red.) M. Budyn-Kulik, P. Kozłowska-Kalisz, M. Kulik, Kodeks karny. Komentarz aktualizowany, LEX nr 534247.

13. Kulik M.: Komentarz aktualizowany do art.165 Kodeksu karnego [w:] M. Mozgawa (red.), M. Budyn - Kulik, P. Kozłowska-Kalisz, M. Kulik, Kodeks karny. Komentarz aktualizowany, LEX nr 534444.

14. Lachowski J.: Komentarz do art. 173 Kodeksu karnego [w:] V. Konarska-Wrzosek (red.), A. Lach, J. Lachowski, T. Oczkowski, I. Zgoliński, A. Ziółkowska, Kodeks karny. Komentarz, LEX nr 10437. 
15. Myszona-Kostrzewa K., Galicki Z. (red.): Pięćdziesiąt lat konwencji tokijskiej bezpieczeństwo żeglugi lotniczej z perspektywy przestrzeni powietrznej i kosmicznej. Księga dedykowana Profesorowi Markowi Żyliczowi, Warszawa 2014, s. 238.

16. Piórkowska-Flieger J.: Komentarz do art. 167 Kodeksu karnego [w:] T. Bojarski (red.) A. Michalska-Warias, J. Piórkowska-Flieger, M. Szwarczyk, Kodeks karny. Komentarz, LEX nr 10269.

17. Postanowienie SN z dnia 16 marca 1999 r., I KZP 32/98.

18. Raglewski J.: Komentarz do art. 113 Kodeksu karnego [w:] W. Wróbel (red), A. Zoll (red.) i inni, Kodeks karny. Część ogólna. Tom I. Część II. Komentarz do art. 53 - 116, LEX nr 10419.

19. Skrzydło W.: Komentarz do art. 55 Konstytucji Rzeczypospolitej Polskiej [w:] W. Skrzydło, Konstytucja Rzeczypospolitej Polskiej. Komentarz, LEX nr 8778.

20. Stefański R.A.: Komentarz do art.166 Kodeksu karnego [w:] M. Filar (red.) i in. Kodeks karny. Komentarz, LEX nr 10366.

21. Uchwała składu 7 sędziów SN z 17 grudnia 2008 r., I KZP 27/08.

22. Uchwała SN z dnia 28 lutego 1975 r., sygn. akt V KZP 2/74.

23. Ustawa z dnia 12 października 1990 r. o ochronie granicy państwowej (Dz. U. 2019 poz. 1776).

24. Ustawa z dnia 6 czerwca 1997 r. Kodeks karny (Dz. U. z 2020 r. poz. 1444).

25. Ustawa $z$ dnia 6 czerwca 1997 r. Kodeks postępowania karnego (Dz. U. 2020 poz. 30).

26. Wyrok SN z 21 maja 1974 r., sygn. akt III KR 407/73.

27. Wyrok SN z 29 stycznia 1972 r., sygn. akt Rw 1532/71.

28. Wyrok SN z dnia 25 lutego 1971 r., I KR 225/70.

29. Wyrok SN z dnia 4 lutego 1993 r., sygn. akt III KRN 254/92.

30. Wyrok SO w Kielcach z dnia 10 grudnia 2013 r., IX Ka 1523/13, LEX nr 1717640.

31. Zoll A.: Komentarz do art. 5 Kodeksu karnego [w:] W. Wróbel, A. Zoll (red.): Kodeks karny. Część ogólna. Tom I. Część I. Komentarz do art. 1-52, LEX nr 10420.

32. Żylicz M.: Prawo lotnicze międzynarodowe, europejskie, krajowe. Wyd. 2, Wydawnictwo Lexis Nexis, Warszawa 2011. 